\title{
Distribution and seasonality of rhinovirus and other respiratory viruses in a cross-section of asthmatic children in Trinidad, West Indies
}

\author{
Jason Matthew ${ }^{1}$, Lexley M Pinto Pereira*1, Tressa E Pappas², \\ Cheri A Swenson ${ }^{2}$, Kris A Grindle ${ }^{2}$, Kathy A Roberg², Robert F Lemanske Jr², \\ Wai-Ming Lee ${ }^{2}$ and James E Gern²
}

Address: ${ }^{1}$ Department of Para-Clinical Sciences, The University of the West Indies, St Augustine, Trinidad and Tobago and ${ }^{2}$ Department of Pediatrics, University of Wisconsin-Madison (UW-Madison), Madison, WI, USA

Email: Jason Matthew - jmatthew2002tt@yahoo.com; Lexley M Pinto Pereira* - lexleyp@gmail.com; Tressa E Pappas - tep@medicine.wisc.edu; Cheri A Swenson - cas@medicine.wisc.edu; Kris A Grindle - kag@medicine.wisc.edu; Kathy A Roberg - kar@medicine.wisc.edu; Robert F Lemanske -rfl@medicine.wisc.edu; Wai-Ming Lee - wlee5@wisc.edu; James E Gern - gern@medicine.wisc.edu

* Corresponding author

\section{Published: 25 June 2009}

Italian Journal of Pediatrics 2009, 35:16 doi:10.1186/1824-7288-35-16

This article is available from: http://www.ijponline.net/content/35/I/I6

(c) 2009 Matthew et al; licensee BioMed Central Ltd.

This is an Open Access article distributed under the terms of the Creative Commons Attribution License (http://creativecommons.org/licenses/by/2.0), which permits unrestricted use, distribution, and reproduction in any medium, provided the original work is properly cited.
Received: 24 February 2009

Accepted: 25 June 2009

\begin{abstract}
Background: Childhood asthma in the Caribbean is advancing in prevalence and morbidity. Though viral respiratory tract infections are reported triggers for exacerbations, information on these infections with asthma is sparse in Caribbean territories. We examined the distribution of respiratory viruses and their association with seasons in acute and stable asthmatic children in Trinidad.

Methods: In a cross-sectional study of 70 wheezing children attending the emergency department for nebulisation and 80 stable control subjects (2 to $16 \mathrm{yr}$ of age) in the asthma clinic, nasal specimens were collected during the dry ( $n=38$, January to May) and rainy $(n=112$, June to December) seasons. A multitarget, sensitive, specific high-throughput Respiratory MultiCode assay tested for respiratory-virus sequences for eight distinct groups: human rhinovirus, respiratory syncytial virus, parainfluenza virus, influenza virus, metapneumovirus, adenovirus, coronavirus, and enterovirus.

Results: Wheezing children had a higher $\left[\chi^{2}=5.561, p=0.018\right]$ prevalence of respiratory viruses compared with stabilized asthmatics $(34.3 \%$ (24) versus (vs.) $17.5 \%$ (I4)). Acute asthmatics were thrice as likely to be infected with a respiratory virus $(\mathrm{OR}=2.5,95 \% \mathrm{Cl}=1.2-5.3)$. The predominant pathogens detected in acute versus stable asthmatics were the rhinovirus (RV) $(n=18,25.7 \%$ vs. $n=7,8.8 \% ; p=$ $0.005)$, respiratory syncytial virus B (RSV B) $(n=2,2.9 \%$ vs. $n=4,5.0 \%)$, and enterovirus ( $n=1,1.4 \%$ vs. $n=2,2.5 \%$ ). Strong odds for rhinoviral infection were observed among nebulised children compared with stable asthmatics $(p=0.005, \mathrm{OR}=3.6,95 \% \mathrm{Cl}=1.4-9.3$,). RV was prevalent throughout the year (Dry, $n=6,15.8 \%$; Rainy, $n=19,17.0 \%)$ and without seasonal association $\left[\chi^{2}=0.028, p=0.867\right]$. However it was the most frequently detected virus $[D r y=6 / 10,(60.0 \%)$; Rainy $=19 / 28,(67.9 \%)]$ in both seasons.

Conclusion: Emergent wheezing illnesses during childhood can be linked to infection with rhinovirus in Trinidad's tropical environment. Viral-induced exacerbations of asthma are independent of seasons in this tropical climate. Further clinical and virology investigations are recommended on the role of infections with the rhinovirus in Caribbean childhood wheeze.
\end{abstract}




\section{Background}

Viral respiratory infections are associated with wheezing illnesses and asthma exacerbations in childhood. Rhinovirus (RV), respiratory syncytial virus (RSV), parainfluenza virus (PIV), human metapneumovirus (hMPV) and influenza virus are the major pathogens that are responsible for early wheezing in infancy $[1,2]$. The Tucson Children's Respiratory Study [3] revealed that lower respiratory tract infection with RSV early in life was associated with persistent wheezing until 11 years of age. More recently Lemanske et al demonstrated that wheezing illnesses due to RV in infancy are the most significant risk factor for the development of persistent wheezing in preschool children [4]

In children above 2 years the rhinovirus is the predominant common cold viral pathogen linked to asthma exacerbations [5]. Viral respiratory tract infections have been the major cause of asthma exacerbations in children [6] with reported prevalence rates of $85 \%$ in exacerbations of childhood asthma [7]. Higher rates of respiratory tract infection are associated with a significant increase in asthma admissions observed every autumn (September November) in the US, Canada, England and Wales [8]. In Canada and France, children who presented to hospitals with asthma exacerbations had a higher prevalence of viral respiratory infections than asymptomatic asthmatic children $[9,10]$.

Studies using conventional and molecular methods to detect respiratory viruses in asthma [6,7], suggest reverse transcriptase polymerase chain reaction (RT - PCR) assays are more rapid, sensitive and specific to detect respiratory viruses compared with conventional techniques such as cell culture. This is especially true for RV, the most common [7] viral trigger for acute exacerbations of asthma.

In the Caribbean, information on respiratory viral infections in childhood asthma is sparse. Using cell culture, Spence et al [11] detected RSV in pharyngeal swabs from 1729 Trinidadian patients with acute respiratory infections from 1964 to 1966 and the majority (90\%) of these was in children below four years of age. Outbreaks of RSV infection in Trinidad and Tobago in 1964, 1965 and 1966 occurred during the rainy season in June, September and August respectively. Most studies examining the prevalence and seasonality of respiratory viruses in association with childhood asthma exacerbations have been conducted in temperate climates, which experience seasons which are considerably different in temperature and rainfall than those in the Caribbean. Trinidad has a tropical climate, with 2 seasons; the dry from January to May, and the rainy from June to December. The average temperatures are similar for the two seasons $\left(27.6^{\circ} \mathrm{C}\right.$ vs. $\left.27.9^{\circ} \mathrm{C}\right)$. The major difference between these seasons is the higher average rainfall [Based on average monthly values between January 2000 to December 2005; data obtained through personal correspondence with Trinidad's Meteorological Office] in the rainy season compared with the dry season (203.4 mm vs. $76.5 \mathrm{~mm}$ ). Being informed by epidemiological data from other geographical locations, we examined if RV was the major viral cause for asthma exacerbations in children in Trinidad, and whether the frequency rates of viral infection differed with seasonality.

\section{Methods \\ Institutional approval}

The Ethics Committee of the Faculty of Medical Sciences at The University of the West Indies, and the Health Sciences Institutional Review Board of the University of Wisconsin-Madison approved the study. The research met compliance set out in the Helsinki Declaration and all children's caregivers signed informed consent to participate.

\section{Subjects}

Subjects with acute asthma exacerbations treated in the Accident and Emergency (A\&E) departments of the Eric Williams Medical Sciences Complex (EWMSC), the San Fernando General Hospital (SFGH) and the Arima Health Facility (AHF) were recruited, through August 2002 to July 2005 (From February 2004 to January 2005 consecutive periods of industrial action in the facilities did not permit patient recruitment). These facilities provide emergency health care and receive patient referrals from the primary health centres. Stable asthmatics were enrolled as they presented at the asthma paediatric clinic of the AHF where asthma education is offered to patients and their parents/ guardians.

\section{Definitions}

Acute asthmatics were defined as asthmatic children who presented to $A \& E$ with an asthma exacerbation and required to be nebulised with a bronchodilator to relieve wheezing and/or tightness in the chest and/or difficulty in breathing. Stable asthmatics were non-symptomatic children who had not suffered any acute exacerbation and did not have any need for nebulisation with a bronchodilator in the previous 3 months.

\section{Inclusion and exclusion criteria}

Children between 2-16 years who had received a physician's diagnosis of asthma and who were attending the asthma clinics were eligible for entry to the study. Children less than two years were not included as it is clinically difficult to differentiate wheezing from asthma as opposed to wheezing of other aetiology in very young children. Subjects who presented to $A \& E$ and required bronchodilator treatment with a nebuliser, but had not been diagnosed with asthma by a physician were not 
included. Although subjects made repeat visits to the paediatric clinic and the A\&E department, they were entered into the study only on the first occasion. Children with incessant cough and infective conditions were excluded from the study.

\section{Sample collection}

Parents or guardians gave their informed written consent for their child to participate. Consecutive patients were invited to participate in the collection of nasal specimens. Some parents or guardians did not consent as they considered their child was too young $(2-4$ years $)$ for the sampling procedure, and others believed this procedure was a further inconvenience to the child who had just been nebulised. Nasopharyngeal mucus specimens were collected using a \#5 Fr feeding tube attached to a $10 \mathrm{ml}$ syringe. Briefly, a maximum volume of $1 \mathrm{ml}$ of sterile saline was administered to the subject's nostril by gently pushing the piston of the syringe; the fluid was then suctioned back into the syringe to obtain the washings of the nasal secretions. The specimens were temporarily stored on wet ice in a cooler and transported within 8 hours of collection to the laboratory (Pharmacology Unit, Faculty of Medical Sciences, The University of the West Indies; Trinidad) where they were separated into 4 aliquots and stored at $70^{\circ} \mathrm{C}$ until the time of shipping on dry ice to Wisconsin. RNA extraction, reverse transcription of RNA and Respiratory MultiCode assay on all specimens were carried out in the Molecular Virology Section of the Pediatric Allergy/ Immunology Research Laboratory at the University of Wisconsin-Madison.

\section{Molecular viral detection}

The Respiratory MultiCode assay (University of Wisconsin-Madison \& EraGen Biosciences, Madison, WI, USA) used in this study is a novel high-throughput assay that utilises MultiCode PLx (EraGen Biosciences, Madison, WI, USA) technology. The assay described previously [12] detects 8 distinct respiratory viruses and their collective 160 plus serotypes on 2 detection panels (panels A6B and C3B) portrayed in Table 1. A 96-well assay is completed in approximately four hours and the multiplexing ability of

Table I: Viruses detected by Respiratory MultiCode assay

\begin{tabular}{ccc}
\hline Virus & Serotypes & \\
\hline Rhinovirus & $>$ IOI & \\
Influenza & A, B & Panel A63B \\
RSV & A, B & \\
Metapneumovirus & A, B & \\
Parainfluenza virus & I, II, III & Panel C3B \\
Adenovirus & $>13$ serotypes of groups B, C, E & \\
Coronavirus & OC43, 229E, NL63, SARS & \\
Enterovirus & $>34$ & \\
\hline
\end{tabular}

the system allows the possibility for more results from the same sample volume, so that minimal quantities of sample are required. Samples were assayed in duplicate with positive and negative controls for each panel of viral detection.

\section{Statistical analysis}

Student's two independent sample t-tests were used to compare differences in the average age between the groups. Chi square tests for independence with the Bonferroni adjustment were used to determine differences in ethnic distribution between the acute and stable asthmatics. Prevalence of viral infections in acute and stable asthmatics and associations of viral prevalence and RV infection with acute asthma and seasons were tested by the chi square $\left(\chi^{2}\right)$ tests for independence. The odds ratios (ORs) with 95\% confidence intervals (CI) determined the likelihood of acute asthmatics (a) being infected with a respiratory virus and (b) having a RV infection compared with stable asthmatics. Student's two independent sample t-tests were used to compare differences in the average age between the groups. The Statistical Package for Social Sciences (Chicago, Illinois, version 13.0) was utilised for data analysis. A p value less than 0.05 was considered statistically significant.

\section{Results \\ Patient profile}

One hundred and fifty (62.8\%) of the 239 children interviewed provided nasal specimens for viral analysis. Similar proportions of samples were collected in the dry and rainy seasons from the two groups of children. Boys $(n=$ $52,74.3 \%$ vs. $n=62,77.5 \%)$ and girls ( $n=18,25.7 \%$ vs. $n=18,22.5 \%)$ were equally distributed $(p=0.646)$ in the acute and stable asthma groups. There was no age difference $[p=0.171]$ between acutely ill ( 8.0 years, $S D=3.5$ ) and stable children $(8.8$ years, $S D=3.2)$. There was a significant $(\mathrm{p}=0.018)$ difference between acute and stable asthmatics in relation to ethnic distribution, so that children of mixed ethnicity $(n=40,65.5 \%)$ were more frequently stable than were Asian Indian children $(\mathrm{n}=11$, $35.5 \%)$. Equal numbers of nasal specimens were collected in the dry $(n=21,30.0 \%$ vs. $n=17,21.3 \%)$ and rainy $(n$ $=49,70.0 \%$ vs. $\mathrm{n}=63,78.8 \%$ ) seasons from the acutely ill and stable asthmatic children respectively ( $\mathrm{p}=0.219]$. (Table 2)

\section{Viral detection in acute and chronic asthmatics}

In children (Table 3 ) who required nebulisation ( $\mathrm{n}=24$, $34.3 \%)$ viral detection was higher $(\mathrm{p}=0.018)$ compared with those $(\mathrm{n}=14,17.5 \%)$ who were stable. Nebulised children were thrice as likely to be infected with a respiratory virus compared with the stable non-symptomatic children $(\mathrm{OR}=2.5,95 \% \mathrm{CI}=1.2-5.3)$. Among children 
Table 2: General information of children $(n=150)$ from whom nasal specimens were obtained

\begin{tabular}{|c|c|c|c|c|c|}
\hline & \multicolumn{2}{|c|}{ Acute $(n=70)$} & \multicolumn{2}{|c|}{ Stable $(n=80)$} & \multirow[t]{2}{*}{ P Value } \\
\hline & No. & $\%$ & No. & $\%$ & \\
\hline \multicolumn{6}{|l|}{ Gender } \\
\hline Male & 52 & 74.3 & 62 & 77.5 & 0.646 \\
\hline Female & 18 & 25.7 & 18 & 22.5 & \\
\hline \multicolumn{6}{|l|}{ Age (years) } \\
\hline Mean (SD) & 8.0 & $(3.5)$ & 8.8 & $(3.2)$ & 0.171 \\
\hline \multicolumn{6}{|l|}{ Ethnicity } \\
\hline African & 29 & 41.4 & 29 & 36.3 & 0.018 \\
\hline Asian Indian & 20 & 28.6 & 11 & 13.8 & \\
\hline Mixed (African \& Asian Indian) & 21 & 30.0 & 40 & 50.0 & \\
\hline \multicolumn{6}{|c|}{ Season specimen was collected } \\
\hline Dry & 21 & 30.0 & 17 & 21.3 & 0.219 \\
\hline Rainy & 49 & 70.0 & 63 & 78.8 & \\
\hline
\end{tabular}

in whom viral presence was detected, the rhinovirus was the most frequent and observed in $75 \%(18 / 24)$ of acute asthmatics and in $50 \%(7 / 14)$ of the stable asthmatics. The rhinovirus was the most common viral pathogen detected $(\mathrm{p}=0.005)$, when comparing acutely ill children $(25.7 \%, \mathrm{n}=18)$ with those who were stable $(8.8 \%, \mathrm{n}=7)$. The likelihood of an acute asthmatic child being infected with RV was 4 times greater than in a stable asthmatic child (OR = 3.6, 95\% CI = 1.4 - 9.3; $\mathrm{p}=0.005)$ (Fig. 1). The RSV B (2.9\% (2) vs 5.0\%(4)), and enterovirus (1.4\%

Table 3: Prevalence of viruses in acute and stable asthmatics

\begin{tabular}{|c|c|c|c|c|}
\hline \multirow[t]{2}{*}{ Virus } & \multicolumn{2}{|c|}{ Acute $(N=70)$} & \multicolumn{2}{|c|}{ Stable $(N=80)$} \\
\hline & No. & $\%$ & No. & $\%$ \\
\hline Total virus $(p=\mathbf{0 . 0 1 8})$ & 24 & 34.3 & 14 & 17.5 \\
\hline Virus not present & 46 & 65.7 & 66 & 82.5 \\
\hline$R V(p=0.005)$ & 18 & 25.7 & 7 & 8.8 \\
\hline $\mathrm{RV} / \mathrm{T}$ otal virus & 0.75 & 75.0 & 0.50 & 50.0 \\
\hline RSVA & 0 & 0.0 & 0 & 0.0 \\
\hline RSV B & 2 & 2.9 & 4 & 5.0 \\
\hline Influenza A & 2 & 2.9 & 0 & 0.0 \\
\hline Influenza B & 0 & 0.0 & 0 & 0.0 \\
\hline Coronavirus OC43 & 1 & $\mathrm{I} .4$ & 0 & 0.0 \\
\hline Coronavirus NL63 & 0 & 0.0 & 1 & 1.3 \\
\hline Coronavirus 229E & 0 & 0.0 & 0 & 0.0 \\
\hline Coronavirus SARS & 0 & 0.0 & 0 & 0.0 \\
\hline EV & I & 1.4 & 2 & 2.5 \\
\hline PIV I & I & 1.4 & 0 & 0.0 \\
\hline PIV 2 & 1 & 1.4 & 0 & 0.0 \\
\hline PIV 3 & 0 & 0.0 & 0 & 0.0 \\
\hline hMPV & 0 & 0.0 & 1 & 1.3 \\
\hline Adenovirus & 0 & 0.0 & 0 & 0.0 \\
\hline Co-infection with 2 viruses & 2 & 2.9 & I & 1.3 \\
\hline -Influenza A \& RSV B & 1 & 1.4 & 0 & 0.0 \\
\hline - Influenza A \&RV & 1 & 1.4 & 0 & 0.0 \\
\hline - RV \& RSV B & 0 & 0.0 & 1 & 1.3 \\
\hline
\end{tabular}

(1) vs $2.5 \%$ (2)) were other common viral pathogens detected in acute and stable asthmatic children respectively. Influenza A (2.9\% (2), coronavirus OC43 (1.4\%(1) and PIV 1 \& 2 (1.4\%(1) were detected in one child each, who had to be nebulised. Coronavirus NL63 and hMPV were each identified in one child who was stable. Coinfection with $>1$ virus was infrequent. Two separate acute asthmatics were positive for Influenza A \& RSV B, and Influenza A \& RV. One child with non-symptomatic asthma was positive for RV \& RSV B. The RSV A, influenza B, coronavirus 229E \& SARS, PIV 3 and adenovirus pathogens were not detected in any child.

\section{Seasonal distribution of viruses detected}

Evidence of viral infection was present throughout the year and highest in February (31.4\%), March (37.5\%) and June $(38.5 \%)$ but was not detected in January and April (Fig 2). Viral detection fell steeply from June to July $(20.0 \%)$ and further in August (12.5\%). A sharp rise in viral identification was observed from August to September $(30.8 \%)$, and appeared to be sustained from October $(28.0 \%)$ to December (26.7\%). Viral prevalence did not differ $(p=0.872)$ in the dry $(n=10,26.3 \%)$ and rainy $(n$ $=28,25.0 \%$ ) seasons (Fig 3 ). Coronavirus OC43 or NL63 $(5.3 \%(2))$ and hMPV $(2.6 \%(1))$ were detected only in the dry season, whereas RSV B (5.4\% (6)), enterovirus $(2.7 \%$ (3)) and influenza A (1.8\%(2)) were identified only in the rainy season. Viral pathogens detected throughout the year were PIV2 (Dry, 2.6\% (1)), PIV1 (Rainy, (0.9\% (1) and RV (Dry, $15.8 \%$ (6); $17.0 \%$ (19). The RV was not associated $(\mathrm{p}=0.867)$ with any particular season, and in both seasons [Dry $=6 / 10,(60.0 \%)$ Rainy $=19 / 28$, $(67.9 \%)]$ it was the most frequently prevalent viral pathogen detected. 


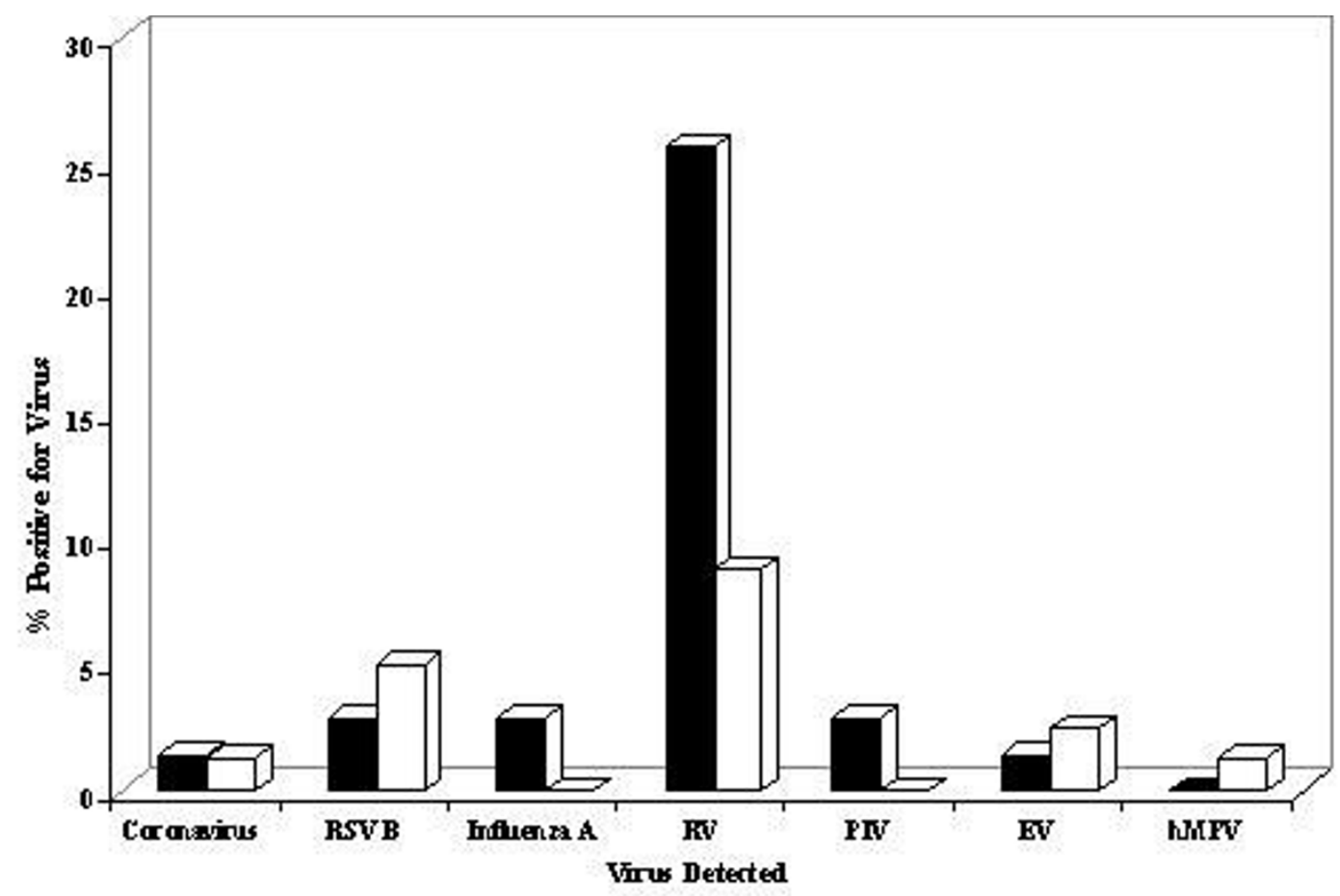

acute $\square$ Stalle

No child demonstrated the presence of RSV A, influenza B, coronavirus 229E, SARS, PIV3 and adenovirus

Figure I

Viruses detected in acute and stable asthmatic children.

\section{Discussion}

This study demonstrates that $34.3 \%$ of children in Trinidad who are wheezing and need to be nebulised have a viral infection. The viral prevalence in children with asymptomatic disease is $17.5 \%$. Our observations on the viral association with paediatric asthma are the first from the Caribbean region and Trinidad in particular where childhood asthma inflicts a burden on the health system [13]. The association of viral infections with exacerbations of wheeze in children with asthma has been reported in temperate climates with higher rates compared with our findings. In Britain viruses were detected in $85 \%$ of children with episodes of wheeze and symptoms of asthma, and rhinovirus was the most frequent virus that was detected [7]. Rakes et al studied infants and children with severe wheezing attending the emergency department in Virginia, USA, and identified rhinovirus in $71 \%$ of those children [5]. However, in France Freymuth et al [6] observed lower rates of rhinovirus as the associated pathogen in $46.9 \%$ of nasal aspirates in hospitalized children who had a severe attack of asthma. As far as these authors are aware viral infections in exacerbations of asthma have not been reported from countries which enjoy warm tropical climates.

In Brazil Camara et al [14] investigated viral infections as risk factors for acute wheezing in children between $0-12$ years and reported RV was not associated with wheezing and did not appear to trigger asthma exacerbations. These findings, they explain, may be attributed to different immunologic responses to RV by the asthmatic population in Brazil compared with other populations studied. They suggest the RV serotypes circulating in the tropics may differ from those in temperate climates, so that the PCR methodology used would not have detected these serotypes. The tropics have higher year-round temperatures which may limit RV replication providing an explanation for the low prevalence rates in this climatic zone compared with those reported from temperate climates. Viral detection rates between exacerbations when children are asymptomatic are very low, to the order of just $3-12 \%$ [15]. Polarized viral infection rates present in temperate climates may result from the wide differences in temperature these regions experience, as opposed to the tropics 


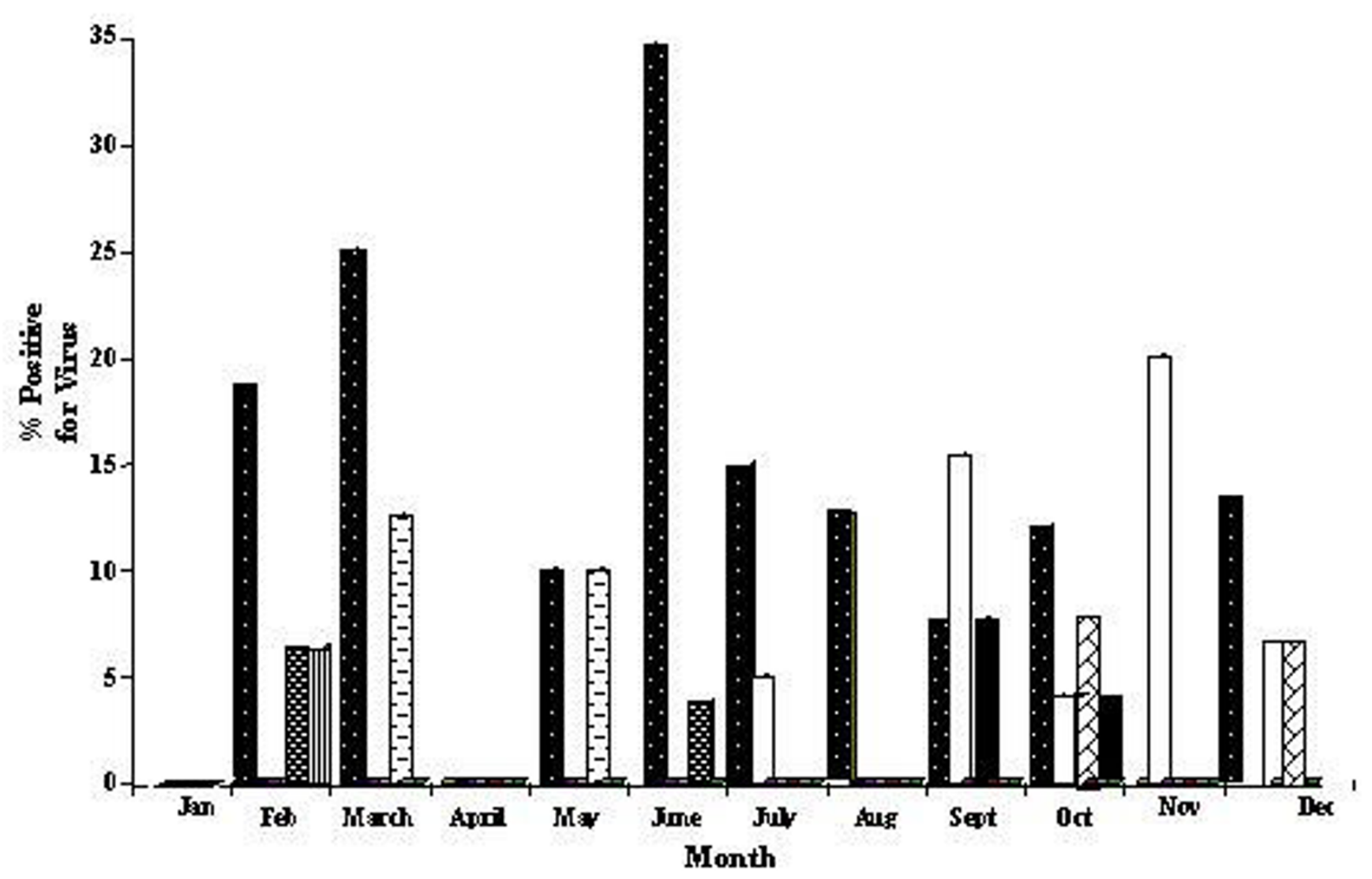

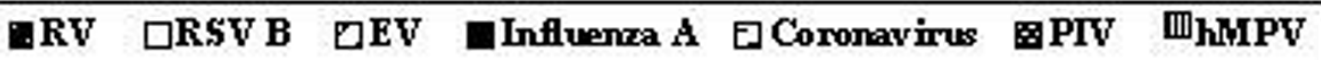

Figure 2

Year round prevalence of respiratory viruses in asthmatic children.

which enjoy relatively continual year-round warmer temperatures, which probably sustain moderate viral presence throughout the year. It may be worth speculating that the viral trigger for exacerbations of asthma may manifest more readily when temperatures are low.

Earlier we observed that children requiring nebulisation were thrice as likely to have a virus infection as did stable children [16]. The common cold/'virus' was a frequently reported trigger of paediatric asthma and children who were nebulised were more likely to have cough, fever or sore throat than did stable children, in the week before they presented at the clinic. Common cold viruses, particularly RV have been implicated as a major trigger for asthma exacerbations. Respiratory tract infections which include the common cold have been associated with an increase in asthma symptoms, hospitalisations and exacerbations [17-19]. Despite the significant association between rhinovirus and exacerbations of asthma observed in the children we studied, the prevalence $(25.7 \%)$ compares poorly with reported rates from France [7], Britain [7] and the USA [5]. Children may have presented to hospital, some days after their initial symptoms, when it might no longer be possible to recover the potential virus that was provocative of the initial illness. Specimens collected in Trinidad, stored, and shipped to another location for processing may have undergone viral attrition during storage, delays in trans-shipment of samples from Trinidad to Wisconsin and thawing of frozen samples.

Increased reactivity during RV infection may be associated with greater changes in airflow limitation, as asthmatic subjects do demonstrate a variable clinical and pathological response [20,21]. The central prevalence of RV among other respiratory viral pathogens isolated signals that in Trinidad's tropical climate it appears to be the major viral trigger for paediatric asthma exacerbations just as reported in the temperate climatic zones. To these authors' knowl- 


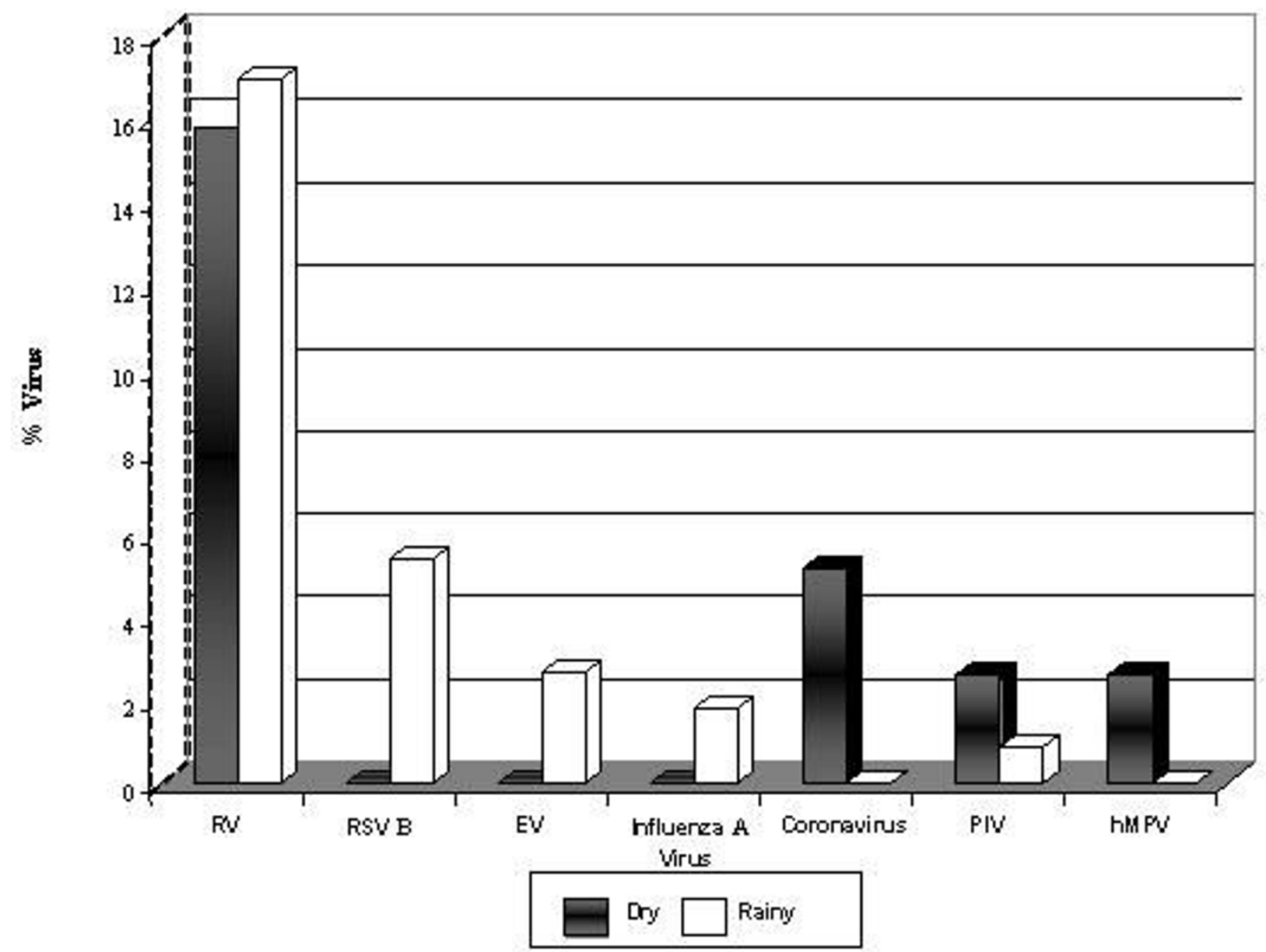

$* \%$ virus $=($ no. of samples positive for particular virus $/$ no. of samples collected for that month $) \times 100$

Figure 3

Respiratory viruses detected in the dry and rainy seasons in children with asthma.

edge, this is the first report linking RV as a major viral trigger for paediatric asthma in the tropics. These findings need to be further explored in longitudinal studies over changing seasons in Trinidad.

In the underlying sample $70 \%$ of children required nebulisation in the rainy season compared with just 30\% of asthmatics in the dry season. Other reports from Trinidad $[13,22]$ Barbados [23] and Mexico City [24] also observed higher disease exacerbations in the rainy season. Even though the overall viral prevalence was higher in the rainy season the difference was not of statistical significance. However the distribution of viruses throughout the year in the present study seems to correspond with reported admission rates in children with asthma in Trinidad $[25,26]$. Admission rates for asthmatic children in Trinidad were reported to be lowest in April [25], relatively low in January and at the lowest point in August in the study period of January to December 1997 [26]. The absence of viral prevalence in January and April, with a nadir in August $(12.5 \%)$ in the present study offers an explanation for these earlier reported observations. The sharp rise in viral detection in September, which remained relatively high for the rest of the year till December correlates with Trinidad's hospital admission data [25] and puts forward justification for the back-to school September peak observed in Trinidad [26] as in Mexico [24], Canada [27], the UK [28] and the US [29].

We detected RSV exclusively in the rainy season (June December). The 1964-1966 RSV outbreaks in Trinidad began in the respective months of June, September and August in the rainy season [11]. A retrospective study from 1982 to 1997 in Malaysia [30], showed a clear association 
between RSV infection rates and the rainy season. In the USA, RSV is most prevalent during the winter months, particularly in January or February [31]. Whether the RSV A strain causes more severe symptoms is controversial $[32,33]$, but only the B subtype RSV strain was detected in children we studied. A low prevalence rate was not unexpected in the children sampled who were between 2 - 16 years as RSV infection is highest below the age of 2 years [34]. The significant lower prevalence of other respiratory viruses in the asthmatic children has been reported in other investigations $[6,7,14]$.

The importance of RV infections in acute asthma has been seen in other studies where it was associated with $71 \%$ $85 \%[5,7]$ of exacerbations, and was also a recognized pathogen for the lower airway [35]. It may be worthwhile to investigate children who wheeze below 3 years for the presence of RV infection. Children with RV-induced wheeze in infancy were 4 times more likely to develop asthma by the age of 6 years than those in whom wheezing was associated with other viruses [36]. Researchers at the University of Wisconsin followed high-risk children (with either one or both parents having had allergies or asthma) from birth to six years in the Childhood Origins of Asthma (COAST) study and evaluated them for the presence of specific viruses during wheezing illnesses. Children who had RV and wheezed during the first year of life were nearly three times as likely to have asthma at six years of age, whereas those children with RSV who wheezed did not have an increased asthma risk. The authors concluded that 'wheezing RV illnesses occurring at any time during the first three years of life were associated with a nearly 10-fold increase in asthma risk at six years', making this viral trigger a significant predictor of asthma development in high risk children. [37]. According to Johnston and co-workers [7] viral infection of the upper airways by common cold viruses frequently triggers a response in the lower airways leading to prolonged morbidity, particularly in those subjects who have significant pre-existing airway disease. Early detection of RV-induced wheeze in very young children assumes clinical importance and encourages close monitoring because of the increased risk of developing early childhood wheeze.

The major viral trigger for paediatric asthma in Trinidad was RV which was not associated with seasonality, suggesting that the virus presents a year round risk factor for asthmatic children in Trinidad. In an earlier study we found children with asthma exacerbations reported symptoms of cold, fever and sore throat that they attributed to a 'cold' in the seven days before visiting the emergency room [16]. These symptoms may have been due to an allergic response mistaken for an infection, or may have been manifestations of a true viral infection. We did not examine children for associated allergic rhinitis which may have contributed to a combination of viral infection and allergen exposure on airway physiology and inflammation. Allergens and viruses may act synergistically to exacerbate asthma in sensitized patients exposing them to an increased risk of exacerbations. In asthmatics even a mild cold is sufficient to induce exacerbations of wheeze, and serious life-threatening asthma attacks are quite likely to occur in association with a severe cold. Spread of viruses through the community to susceptible individuals may be the single most important cause of sustained exacerbations of asthma in children. We suggest strategies to reduce the impact of asthma exacerbations should include interventions directed at viruses, as well as at reducing allergen exposure. Factors other than allergens and viruses, such as air pollution and cigarette smoking should also be examined, in addition to unavailability of and non-compliance with treatment, which was observed in asthmatics attending the Chest Clinic in Trinidad [38]. Caregivers of asthmatic children must be educated to recognize the pro-dromal symptoms associated with viral upper respiratory tract infections so that prompt and aggressive anti-inflammatory controller medication can be initiated.

\section{Conclusion}

As in temperate climates RV presents a risk factor as the major viral trigger for asthmatic children in Trinidad. Viral-induced exacerbations of asthma are independent of seasons in this tropical climatic zone. This study provides a basis for further clinical and virology investigations on the role of RV infections in Caribbean childhood wheeze. As an important clinical implication early prevention and treatment of exacerbations of wheeze in children should focus on upper respiratory tract viral infections. Such strategies may assist to optimize healthcare in paediatric asthma and reduce its burden in this tropical region.

\section{Abbreviations}

(RSV): Respiratory synctial virus; (RV): Rhinovirus; (A\&E): Accident and Emergency; (EWMSC): Eric Williams Medical Sciences Complex; (SFGH): San Fernando General Hospital; (AHF): Arima Health Facility; (hMPV): human Metapneumovirus; (SARS): Severe Acute Respiratory Syndrome; (PIV): parainfluenza virus; (PCR): polymerase chain reaction; $(\mathrm{CI})$ : confidence intervals.

\section{Competing interests}

The authors declare that they have no competing interests.

\section{Authors' contributions}

JM did the sample collection, laboratory and statistical analysis and prepared the draft of the manuscript. LMPP conceived, designed, supervised and co-ordinated the study and prepared the final manuscript. TEP, CAS, KAG, and KAR participated with the viral assays and co-ordi- 
nated the ethical approval. WML standardized the methodology on the high-throughput assay and trained on its application. JE and RFL were senior supervisors at the University of Wisconsin who critiqued the analysis, data, results, and manuscript. JE lent significant personal support and encouragement during the analysis and the conclusions. All authors approved the final manuscript.

\section{Acknowledgements}

Dr. Beni Balkaran and Dr Solaiman Juman trained on collecting nasal specimens. Dr. Jasmine Ramcharan and Nurse Franka Andrews assisted in recruiting patients at the AHF pediatric asthma clinic. Dr Isaac Bekele guided on the statistical analysis. The study was supported by a Dean's Award for Postgraduate Research from The University of the West Indies. The University of Wisconsin-Madison provided all laboratory facilities and re-agents for the analytical work.

\section{References}

I. Heymann PW, Carper HT, Murphy DD, Platts-Mills TA, Patrie J, McLaughlin AP, Erwin EA, Shaker MS, Hellems M, Peerzada J, Hayden FG, Hatley TK, Chamberlain R: Viral infections in relation to age, atopy, and season of admission among children hospitalized for wheezing. J Allergy Clin Immunol 2004, I I 4:239-247.

2. Jartti $T$, Lehtinen $P$, Vuorinen $T$, Osterback R, Hoogen $B$ van den, Osterhaus $A D$, Ruuskanen $O$ : Respiratory picornaviruses and respiratory syncytial virus as causative agents of acute expiratory wheezing in children. Emerg Infect Dis 2004, 10:1095-I I0I.

3. Stein RT, Sherrill D, Morgan WJ, Holberg CJ, Halonen M, Taussig LM, Wright AL, Martinez FD: Respiratory syncytial virus in early life and risk of wheeze and allergy by age 13 years. Lancet 1999, 354:54I-545.

4. Lemanske RF Jr, Jackson DJ, Gangnon RE, Evans MD, Li Z, Shult PA, Kirk CJ, Reisdorf E, Roberg KA, Anderson EL, Carlson-Dakes KT, Adler KJ, Gilbertson-White S, Pappas TE, Dasilva DF, Tisler CJ, Gern JE: Rhinovirus illnesses during infancy predict subsequent childhood wheezing. J Allergy Clin Immunol 2005, I I 6:57 I-577.

5. Rakes GP, Arruda E, Ingram JM, Hoover GE, Zambrano JC, Hayden FG, Platts-Mills TA, Heymann PW: Rhinovirus and respiratory syncytial virus in wheezing children requiring emergency care. IgE and eosinophil analyses. Am J Respir Crit Care Med I999, 1 59:785-790.

6. Freymuth F, Vabret A, Brouard J, Toutain F, Verdon R, Petitjean J, Gouarin S, Duhamel JF, Guillois B: Detection of viral, Chlamydia pneumoniae and Mycoplasma pneumoniae infections in exacerbations of asthma in children. J Clin Virol 1999, 13:131-139.

7. Johnston SL, Pattemore PK, Sanderson G, Smith S, Lampe F, Josephs L, Symington P, O'Toole S, Myint SH, Tyrrell DA, Holgate ST: Community study of role of viral infections in exacerbations of asthma in 9-II year old children. BMJ 1995, 3 I0: I 225-I 229.

8. Dales RE, Schweitzer I, Toogood JH, Drouin M, Yang W, Dolovich J, Boulet J: Respiratory infections and the autumn increase in asthma morbidity. Eur Respir J 1996, 9:72-77.

9. Johnston NW, Johnston SL, Duncan JM, Greene JM, Kebadze T, Keith PK, Roy M, Waserman S, Sears MR: The September epidemic of asthma exacerbations in children: a search for etiology. J Allergy Clin Immunol 2005, I I 5: I 32- I 38.

10. Thumerelle C, Deschildre A, Bouquillon C, Santos C, Sardet A, Scalbert M, Delbecque L, Debray P, Dewilde A, Turck D, Leclerc F: Role of viruses and atypical bacteria in exacerbations of asthma in hospitalised children: a prospective study in the Nord-Pas de Calais Region (France). Pediatr Pulmonol 2003, 35:75-82.

II. Spence L, Barratt N: Respiratory syncytial virus associated with acute respiratory infections in Trinidadian patients. Am J Epidemiol 1968, 88:257-266.

12. Lee WM, Grindle K, Pappas T, Marshall DJ, Moser MJ, Beaty EL, Shult PA, Prudent JR, Gern JE: High-throughput, sensitive, and accurate multiplex PCR-microsphere flow cytometry system for large-scale comprehensive detection of respiratory viruses. J Clin Microbiol 2007, 45:2626-2634. Epub 2007 May 30
13. Mohammed F, Bootoor S, Panday A, Ramdass A, Reemaul J, Sharma A, Ivey M, Pinto Pereira LM: Predictors of repeat visits to the emergency room by asthmatic children in primary care. J Natl Med Assoc 2006, 98: | 278-1285.

14. Camara AA, Silva JM, Ferriani VP, Tobias KR, Macedo IS, Padovani MA, Harsi CM, Cardoso MR, Chapman MD, Arruda E, Platts-Mills TA, Arruda LK: Risk factors for wheezing in a subtropical environment: role of respiratory viruses and allergen sensitization. J Allergy Clin Immunol 2004, I I 3:55 I-557.

15. Johnston SL: Viruses and asthma. Allergy 1998, 53:922-932.

16. Matthew J, Ramcharan J, Pinto Pereira LM: Viral infections and dust are triggers for pediatric asthma in Trinidad, West Indies [abstract]. European Respiratory Journal 2004, 24:s48.

17. Lambert HP, Stern H: Infective factors in exacerbations of bronchitis and asthma. BrMed J 1972, 3:323-327.

18. Minor TE, Dick EC, Baker JW, Ouellette JJ, Cohen M, Reed CE: Rhinovirus and influenza type $A$ infections as precipitants of asthma. Am Rev Respir Dis 1976, I I 3:149-153.

19. National Heart, Lung, and Blood Institute National Asthma Education and Prevention Program Expert Panel Report 3: Guidelines for the Diagnosis and Management of Asthma Full Report 2007 [http://www.nhlbi.nih.gov/guidelines/asthma/ asthgdln.pdf]

20. Bardin PG, Fraenkel DJ, Sanderson G, van Schalkwyk EM, Holgate ST, Johnston SL: Peak expiratory flow changes during experimental rhinovirus infection. Eur Respir J 2000, 16:980-985.

21. Fraenkel DJ, Bardin PG, Sanderson G, Lampe F, Johnston SL, Holgate ST: Lower airways inflammation during rhinovirus colds in normal and in asthmatic subjects. Am J Respir Crit Care Med 1995, I 5 I:879-886.

22. Ivey MA, Simeon DT, Monteil MA: Climatic variables are associated with seasonal acute asthma admissions to accident and emergency room facilities in Trinidad, West Indies. Clin Exp Allergy 2003, 33: I526-1530.

23. Depradine C, Moseley HSL, Roach TR: Weather and bronchial asthma in Barbados - A Preliminary Report. West Indian Med ] 1984, 33:s24.

24. Rosas I, McCartney HA, Payne RW, Calderón C, Lacey J, Chapela R, Ruiz-Velazco S: Analysis of the relationships between environmental factors (aeroallergens, air pollution, and weather) and asthma emergency admissions to a hospital in Mexico City. Allergy 1998, 53:394-40I.

25. Monteil MA: Asthma in the English-speaking Caribbean. West Indian Med J 1998, 47:125-128.

26. Monteil MA, Juman S, Hassanally R, Williams KP, Pierre L, Rahaman $M$, Singh $H$, Trinidade A: Descriptive epidemiology of asthma in Trinidad, West Indies. J Asthma 2000, 37:677-684.

27. Johnston NW, Sears MR: A national evaluation of geographic and temporal patterns of hospitalization of children for asthma in Canada [abstract]. Am J Respir Crit Care Med 200I, 163:s359.

28. Storr J, Lenney W: School holidays and admissions with asthma. Arch Dis Child 1989, 64:103-107.

29. Gergen PJ, Mitchell H, Lynn H: Understanding the seasonal pattern of childhood asthma: results from the National Cooperative Inner-City Asthma Study (NCICAS). J Pediatr 2002, 141:631-636.

30. Chan PW, Chew FT, Tan TN, Chua KB, Hooi PS: Seasonal variation in respiratory syncytial virus chest Infection in the tropics. Pediatr Pulmonol 2002, 34:47-5I.

31. Shay DK, Holman RC, Newman RD, Liu LL, Stout JW, Anderson LJ: Bronchiolitis-associated hospitalizations among US children, 1980-1996. JAMA 1999, 282: I440-1446.

32. McConnochie KM, Hall CB, Walsh EE, Roghmann KJ: Variation in severity of respiratory syncytial virus infections with subtype. J Pediatr 1990, I1 7:52-62.

33. Kneyber MC, Brandenburg AH, Rothbarth $\mathrm{PH}$, de Groot R, Ott A, van Steensel Moll HA: Relationship between clinical severity of respiratory syncytial virus infection and subtype. Arch Dis Child 1996, 75: I37-140.

34. Denny FW, Collier AM, Henderson FW, Clyde WA Jr: Infectious agents of importance in airways and parenchymal diseases in infants and children with particular emphasis on bronchiolitis. The epidemiology of bronchiolitis. Pediatr Res 1977, II:234-236. 
35. Gern JE, Galagan DM, Jarjour NN, Dick EC, Busse WW: Detection of rhinovirus RNA in lower airway cells during experimentally-induced infection. Am J Respir Crit Care Med 1997, 155: II59-II6I.

36. Kotaniemi-Syrjanen A, Vainionpaa R, Reijonen TM, Waris M, Korhonen K, Korppi M: Rhinovirus-induced wheezing in infancy - the first sign of childhood asthma? J Allergy Clin Immunol 2003, II I:66-7I.

37. Jackson DJ, Gangnon RE, Evans MD, Roberg KA, Anderson EL, Pappas TE, Printz MC, Lee WM, Shult PA, Reisdorf E, Carlson-Dakes KT, Salazar LP, DaSilva DF, Tisler CJ, Gern JE, Lemanske RF Jr: Wheezing rhinovirus illnesses in early life predict asthma development in high-risk children. Am J Respir Crit Care Med 2008, 1 78:667-672. Epub 2008 Jun 19.

38. Pinto Pereira LM, Clement Y, Da Silva CK, Mclntosh D, Simeon DT: Understanding and use of inhaler medication by asthmatics in specialty care in Trinidad: a study following development of Caribbean guidelines for asthma management and prevention. Chest 2002, I 2 I:1833-1840.

Publish with Bio Med Central and every scientist can read your work free of charge

"BioMed Central will be the most significant development for disseminating the results of biomedical research in our lifetime. "

Sir Paul Nurse, Cancer Research UK

Your research papers will be:

- available free of charge to the entire biomedical community

- peer reviewed and published immediately upon acceptance

- cited in PubMed and archived on PubMed Central

- yours - you keep the copyright

Submit your manuscript here:

http://www.biomedcentral.com/info/publishing_adv.asp
BiolMedcentral 